\title{
Economic Valuation of Rice Paddy Biomass: Case Study at Village of Sukakarya, Regency of Bekasi)
}

\author{
Nandang Najmulmunir', Ahya Kamilah ${ }^{2}$ And Sirly Amaliah ${ }^{3}$ \\ \{nanduz2000@gmail.com ${ }^{1}$, langitbiru1982@gmail.com ${ }^{2,3}$ \\ 1,2,35aculty of Agriculture Universitas Islam "45", Jl. Cut Mutiah 83 Bekasi 17113, \\ Indonesia
}

\begin{abstract}
The study aims to determine the economic value of rice Paddy biomass. Primary data was obtained through interviews and field observations through harvesting rice biomass. The results show that biomass has a very important economic value, that is divided into Direct and Indirect Economic Value.
\end{abstract}

Keywords: Please list your keywords in this section.

\section{Introduction}

The supply of rice food for the Indonesian population always increases every year along with the increase in number of population and an increase of rice consumption per capita. Therefore an increasing of rice production is a strategic program to fulfill food demand, so it is always used as a priority program in agricultural development [8].

Food crop development was done through efforts to increase the productivity of rice field of land. Bekasi District is one of the centers of food production which has produced paddy rice for about 609,585 tons in 2013. This production has increased compared to production in 2012 which reached 597,027 tons. This increase in production was due to the addition of harvested area from 96,288 hectares in 2012 to 98,425 hectares in 2013 [2].

Rice cultivation needs to be adapted to agricultural environmental conditions, such as biophysics, soil mineral reserves, availability of organic matter, availability of inputs and technology. For the present condition of rice environment, it only relies on inorganic input and does not prioritize the use of organic material. For future rice farming, organic matter, microorganisms, nutrients and soil minerals will be the mainstay of input in situ rice production systems [8].

Rice is unique in that it can only be affected by trace gases such as $\mathrm{CO}_{2}$ but may also make a significant contribution to other global warming gases such as $\mathrm{CH}_{4}$ [9]. Rice stands have high benefits, which so far have only been based on the amount of grain as a result of grain, but the rice straw is very useful as for organic fertilizers, storing carbon in the atmosphere (carbon sequestration), sources of nutrients for plants and soil health. Therefore, the economic value is very large, not limited to grain yields. The return of crop residues and the application of manures and fertilizers can be combined with a management system for more improvement [18].

Economic valuation is needed for estimating the value of environmental goods and services. Resource economic valuation is an economic tool that uses certain valuation techniques to estimate the money value of goods and services produced by natural and 
environmental resources. Economic valuation is needed for decision makers to estimate the efficiency of the economy of natural resources utilization [12].

Economists have developed a valuation method to measure the value of natural resource and environmental management, especially for goods and services that have no market value ( 14], [1] Measuring or calculating the total value of rice paddy plant in the theory of resource environments using the total economic value (TEV). Total Economic Value (TEV) is the sum of economic value-based utilization or Use value (UV) and value-based economic on nonutilization or Non-Use Value (NUV).

Use Value consists of direct use value (DUV), indirect use value (IUV), and options value $(\mathrm{OV})$. Meanwhile, economic value is not based on market price is non Use Value (NUV). It is consists of two components, namely the bequest value (BV) and existence value (EV) [6]. This study aims to determine the magnitude of the economic value of biomass originating from rice plants, especially with the value of direct benefits and indirect one.

\section{Methodology}

The method used was survey of the farmers who have a characteristic features of the background characteristics and characteristics that are typical of the case, type of approach, and the review of one case is carried out intensively, deeply, in detail, and comprehensively [5]

The data used in this study consisted of primary data and secondary data. The population in this study was rice plants in Sukakarya Village. Sampling by harvesting in situ, this method is a way of retrieving rice stand structure by harvesting all parts of the plant including its roots, drying and weighing the yields [16]

\subsection{Direct Use Value}

Direct economic value is the amount of grain produced based on the price, according to the formula as follow

$$
\mathrm{EVC}=\mathrm{Q} \times \mathrm{P} \times \mathrm{BPT}
$$

Where: $\mathrm{EVC}=$ Economic value of crop production $(\mathrm{IDR} / \mathrm{ha}) ; \mathrm{Q}=$ Total Production $(\mathrm{Kg} / \mathrm{ha})$; $\mathrm{P}=$ Price $(\mathrm{IDR} / \mathrm{Kg})$

\subsection{Indirect Use Value}

IUV used the surrogate market. This method uses the price of goods that can be marketed as a substitute for the environment which is considered to be close to the value of environmental goods and services produced by a natural resource.

\subsection{Economic Valuation}

Economic valuation is needed in deciding the choice of development policies related to resources allocation. The total benefit value of lowland rice is the sum of all economic values of the resource benefits that have been identified and quantified. The total benefit value uses the equation as follow:

$$
\mathrm{TEV}=\mathrm{DUV}+\mathrm{IUV}+\mathrm{OV}+\mathrm{EV}
$$

Where: $\mathrm{TEV}=$ Total economic value; $\mathrm{DV}=$ Direct use value; IUV = Indirect Use Value; OV $=$ Option Value and EV $=$ Existence Value 


\section{Results and Discussion}

\subsection{Direct Use Value}

The benefits of rice paddy plants are derived from the grain of rice as a staple food source of the Indonesian Nation. The economic value of rice grains is based on market prices. The economic value of rice grains is a real economic and is included in the Direct Use Value (DUV) category. The economic value of rice grains is presented in Table 1. Economic value of rice grains in the unit of analysis in one hectare, agricultural area at the village level and rice fields in Bekasi district level.

Table 1. Economic Value of Paddy Grain of Bekasi's District

\begin{tabular}{lllll}
\hline Unit Analysis & Area (ha) & Yield (kg) & $\begin{array}{c}\text { Unit Price } \\
(\text { IDR } / \mathrm{kg})\end{array}$ & Value (IDR) \\
\hline Hectare & 1 & 6,300 & 4923 & $31,014,900$ \\
Village of Sukakarya & 517.8 & $3,262,140$ & 4923 & $16,059,515,220$ \\
District of Bekasi & 96550 & $608,265,000$ & 4923 & $2,994,488,595,000$ \\
\hline
\end{tabular}

Source: primary data

Table 1 shows that rice productivity on average per one season is 6.3 tons per hectare with an economic value of IDR 31,014,900 per hectare. Whereas for the area of village level it can produce economic value of IDR. 16,059,515,220. This income can have an impact on rural development, which is expected to be a driver of the economy both in terms of its backward and forward linkages.

The development of the food crop sector will have a double impact on the regional economy, both the generation of production input markets and the production output market, so that overall it can be a mover to all economic sector in the regional economy. The economic value of food sources for the District scale is IDR 2,994,488,595,000 per one season, while for one year it is estimated to double for about IDR 6 trillion.

\subsection{Indirect Use Value}

The indirect benefits of the components of rice paddy plant are rice straw and roots. Its use is still limited only for a medium for mushroom media and roots left in the soil as raw material for organic compost. Both of these components have more benefits for farmers, but these two components have not been fully utilized properly by local farmers, even though organic matter is the most important component of building soil fertility [11].

There is a detrimental action by farmers, namely by burning straw. This action has an impact on accelerating the loss of organic materials and soil nutrients, increasing $\mathrm{CO} 2$ emissions, causing air pollution, and reducing soil microbial activity [7]. Economic value straw biomass is based on the cost of the transport from the rice field to the location of use. This method still does not represent the actual value. The economic value of straw can be seen in Table 2 below. 
Table 2. Economic Value of Indirect Use Value of Rice Straw Biomass.

\begin{tabular}{lllll}
\hline Unit of Analysis & Area (ha) & Yield (kg) & $\begin{array}{l}\text { Unit Price } \\
\text { (IDR/kg) }\end{array}$ & Value (IDR) \\
\hline Hectare & 1 & 15,700 & 500 & $78,500,000$ \\
Village of Sukakarya & 517.8 & $8,129,460$ & 500 & $4,064,730,000$ \\
District of Bekasi & 96,550 & $1,515,835,000$ & 500 & $757,917,500,000$ \\
\hline
\end{tabular}

Source: primary data

Table 2 explains the amount of rice straw, which has not been utilized maximally. Rice straw as a biomass produced a value of IDR 78,500,000. For agricultural areas in one village unit with an area of 517.8 ha yielding straw amounting to $8,129,460 \mathrm{~kg}$ of straw with a value of IDR 4,064,730,000. For one District of Bekasi produced very large organic material from the total area of rice planting as much as 96,500 ha, it can produce economic value of IDR. $757,917,500,000$. Although it does not have a real economy, it at least provides information regarding the availability of biomass resources in the development of local agriculture.

The root rice paddy plant is part of the biomass, which left in the soil as soil organic material. The amount of root embedded in the soil is presented in Table 3.

Table 3. Economic Value of Root Plant Biomass of Rice Paddy

\begin{tabular}{lllll}
\hline Unit of Analysis & Area (ha) & Yield (kg) & $\begin{array}{l}\text { Unit Price } \\
\text { (IDR/kg) }\end{array}$ & Value (IDR) \\
\hline Hectare & 1 & 713 & 500 & 356,500 \\
Village of Sukakarya & 517.8 & $369,191.4$ & 500 & $184,595,700$ \\
District of Bekasi & 96,550 & $68,840,150$ & 500 & $34,420,075,000$ \\
\hline
\end{tabular}

Source: primary data

Indirect benefits per hectare is the calculation of the potential value of root straw in hectares per season, with production per hectare was $713 \mathrm{~kg}$, at the value of IDR 356,500 in one planting season. Rice roots do not have a market price, so the value is based on surrogate market prices of IDR. 500 per Kg. At this price, the gross value for each one hectare is IDR 356,500 per season. This price refers to the acquisition price of organic fertilizer raw materials, so that the value does not reflect the maximum benefits. The number of roots at the village level in the area of paddy rice with an area of 517.8 hectares was $369,191.4 \mathrm{~kg}$, It was equal to IDR $184,595,700$ while for the area of rice paddy fields in the District level is IDR. $34,420,075,000$ for $68,840,150 \mathrm{~kg}$ of biomass of root.

\subsection{Total Economic Value of Bekasi District}

The rice paddy biomass presented in Table 4 . It shows that the total physical amounts at the district level are $2,192,940,150 \mathrm{~kg}$, in the form of straw biomass. It is consist of $28 \%$ rice grains, $69 \%$ rice straw and 3\% roots. The biomass can be used optimally to add soil nutrients. Use of straw compost as a source of $\mathrm{K}$ or as a substitute for inorganic fertilizer of $\mathrm{KCl}$. Manure is given as a source of $\mathrm{N}, \mathrm{P}, \mathrm{K}, \mathrm{Ca}$ and others or equivalent to compound fertilizers [8]. Mahmoud suggested that the application of compost rice or water treatment residuals (WTR) showed a reduction in soil salinity, $\mathrm{Cl}^{-}$and $\mathrm{Na}^{+}[10]$. 
Table 4. The Amount of Paddy Rice Biomass at District Level

\begin{tabular}{lll}
\hline Component of Paddy Rice Biomass & Amount $(\mathrm{kg})$ & Percent \\
\hline Grain & $608,265,000$ & $28 \%$ \\
Rice Straw & $1,515,835,000$ & $69 \%$ \\
Root of rice plant & $68,840,150$ & $3 \%$ \\
Total physical amount & $2,192,940,150$ & \\
\hline Source: primary data & &
\end{tabular}

Total economic value is the sum of the value of direct use and indirect use. The total economic value can be seen in Table 5. The value of rice paddy consist of Direct Use Value and Indirect Use Value with the amounts was IDR. 39,221,400 for one hectare and for Sukakarya Village level was IDR. 20,308,840,920 and For District level was IDR $3,786,826,170,000$.

Table 5. The Total Economic Value of Rice Paddy Biomass

\begin{tabular}{llc}
\hline Unit of Analysis & Area (ha) & Value (IDR) \\
\hline Hectare & 1 & $39,221,400$ \\
Village & 517.8 & $20,308,840,920$ \\
District & 96550 & $3,786,826,170,000$ \\
\hline
\end{tabular}

Source: primary data

The Table 6 shows that the total economic value is IDR 39,221,400. It is consist of direct benefits category with the value for about $79 \%$ and indirect benefits category is consists of $21 \%$. This result is in line with the research that the economic potential value of mangroves in East Sinjai is IDR $37,535,809,496$ per year.

Table 6. Total Economic Value of Rice Paddy Biomass

\begin{tabular}{lll}
\hline Component of Value & Value (IDR) & Percent \\
\hline Direct Use Value & $31,014,900$ & $79 \%$ \\
Indirect Use Value & $8,206,500$ & $21 \%$ \\
Total & $39,221,400$ & \\
\hline
\end{tabular}

Source: primary data

Indirect values contributed the highest portion to total income $(52.43 \%)$, followed by direct values $(46.26 \%)$, existence value $(0.90 \%)$ and option value $(0.41 \%)$ respectively. [14]

Biomass has a strategic value as the carbon binder with a large potential to reduce carbon in the atmosphere and store it in the soil, besides being useful for mitigating climate change, improve soil health and increase farmers' income. The addition of liquid organic fertilizer to rice plantations in organic farming systems was able to increase the yield of harvested dry grain by $4.4 \%-17.4 \%[16]$ 


\section{Conclusion}

Based on the results of the analysis and discussion of the problems expressed above, some conclusions can be drawn, namely:

1) Rice paddy plant are biomass which is divided into several parts, namely grain, straw and roots which have direct and indirect use values.

2) The direct benefit of paddy rice per hectare is IDR 31,014,900 and Indirect Value of IDR $8,206.50$ and overall the total economic value is IDR 39,221,400.

3) Economic value can be even greater if the biomass components are developed based on more benefits.

\section{References}

[1]. Anggraeni, R. 2008. Economic Valuation of the Coral Reef System of Karimunjawa National Park. Essay. Marine Fisheries Business and Economic Management. Faculty of Fisheries and Marine Affairs. IPB

[2]. BPS. 2014. Bekasi in Figures 2013. Bekasi District Statistics Agency. Bekasi District. West Java

[3]. BPS. 2014. Harvest Area, Production and Productivity of Lowland Rice in West Java Province in the last 5 years. Indonesian Central Bureau of Statistics. Jakarta.

[4]. Darusman D and Widada. 2004. Conservation in the Development Economic Perspective. Bogor: Directorate General of PHKA.

[5]. Faisal, S. 2008. Format - Format of Social Research. Jakarta: Rajawali Press.

[6]. Freeman III, A.M. 2003. The Measurement of Environmental and Resource Values. Resources for the Future. Washington, D.C.

[7]. Ghoneim. A. 2008. The impact of the $15 \mathrm{~N}$ labeled rice straw and rice straw composted the application on mineralization and uptake by rice. International Journal of Plant Production 2 (4), October 2008. ISSN: 1735-6814 (Print), 1735-8043 (Online)

[8]. Makarim, AK and E. Suhartatik 2006. Rice Cultivation with In Situ Input Towards Future Occupation. Food Crop Science and Technology. 1: 19-29.

[9]. Neue, Heinz-Ulrich,; Ziska, Lewis, Matthews, Robin, Dal Qiujie. 1995. Reducing Global Warming - The Role of Rice. GeoJournal. 351-362.35.3. International Rice Research Institute.

[10]. Mahmoud, Esaway, Ibrahim, Mahmoud, Robin, Paul and Akkal-Corfini, Nouraya and El-Saka, Mohamed. 2009. Rice Straw Composting and Its Effect on Soil Properties. Compost Science \& Utilization, (2009), Vol. 17, No. 3, 146-150

[11]. Pringadi, Kasdi.(2009). The role of organic materials in increasing sustainable rice production supports national food security. Agricultural Innovation Development 2 (1), 2009: 48-64.

[12]. Santosa, Edi., P. Hadi, Sudharto and Y, Warella. 2013. Payment for Environmental Services and Polder Sustainable Management in the Context for Poverty Reduction in Semarang. Journal of Government and Politics Vol.4 No.2 August 2013. http://dx.doi.org/10.18196/jgp.2013.0021. Accessed on 15 of August.2018.

[13]. Soemarno. 2010. Economic Valuation Method of Agricultural Land Resources. Abstractions and Summaries of the MK Study Material. Natural Resource Economics. PDIP PPS FPUB.

[14]. Suparmoko M. 2006. Guide and Analysis of Valuation of Natural Resource Economics and Environment. First print: BPFE- Yogyakarta. 
[15]. Suharti, S., Darusman, D., Bramasto, N., and Sundawati, L. 2016. Economic Valuation As a Base for Sustainable A Case in East Sinjai Resource Management, South Sulawesi. JMHT Vol. 22, (1): 13-23, April 2016. EISSN: 2089-2063. DOI: 10.7226 / jtfm.22.1.13

[16]. Sutaryo, Dandun. 2009. Calculation of Biomass. Wetlands International Program, Bogor.

[17]. Supartha I Nyoman Yogi and Adnyana, Winaja, Gede and Adnyana, Gede Menaka. 2012. Application of Organic Fertilizer Types to Rice Plants Organic Agriculture Systems. E-Journal of Tropical Agroecotechnology ISSN: 2301-6515 Vol. 1, No. 2, October 2012.

[18]. X. Liu1, Herbert, S.J., Hashemi, A.M., X. Zhang, G. Ding. 2006. Effects of on soil organic matter agricultural management and carbon transformation - a review. PLANT SOIL ENVIRON., 52, 2006 (12): 531-543. 